\title{
1. The emergence of transatlantic agricultural tensions (1957 to 1971)
}

\section{INTRODUCTION}

The formation of the European Economic Community (EEC) ${ }^{1}$ in 1957 posed a critical dilemma for the US. On political grounds it provided a capstone to the rebuilding of Western Europe as an ally against the USSR and as a bulwark of democracy in an unstable world. A strong European economy was also beneficial to the US as a market for US exports and the countries could be co-leaders of the path towards open markets and an entrepreneurial private sector. But the US was also concerned about the potential emergence of protectionist policies in the EEC, in particular in the agricultural sector. The six members of the EEC each had, to varying degrees, interventionist agricultural policies, and it was clear that there was to be a common agricultural policy. The fear was that the EEC would adopt some of the more protectionist aspects of the national policies. This led to attempts to negotiate tariff reductions within the GATT. The EEC in any case had (under GATT rules) to negotiate with those trade partners that suffered from increased tariffs as the Common External Tariff was introduced. This negotiation merged into the Dillon Round in 1961, when the EEC and the US traded tariff-cutting offers but ultimately failed to reach an acceptably ambitious deal. As a consequence the US tried a broader approach and in 1964 launched the Kennedy Round, which was to achieve a substantial tariff reduction in manufactured goods. However, agriculture proved to be the most difficult sector to address in the Dillon and Kennedy Rounds of trade negotiations, in part because of the prevalence of nontariff support measures, and the fault lines between the US and the EEC were drawn. By the end of the 1960s the policy differences had hardened

\footnotetext{
${ }^{1}$ In the course of European integration, the EEC changed names a number of times. As a matter of convenience, the term EEC will be used in the first two chapters of the book, dealing with a historical period when this term was typically used, and switch to the term EU thereafter (leaving out the term EC that was actually used in between and continued to be used in the GATT and WTO context until recently).
} 
into fundamental disagreements on the desirable development of world agricultural trade.

Agricultural policy tensions and acrimonious trade relations were in many respects reflections of the changing geo-political realities in that era. The 1960s were a period of transition from US hegemony in the post-war period towards a (somewhat unequal) partnership that emerged in the 1970s. The main issues on the transatlantic agenda at the start of the decade had to do with the containment of Soviet ambitions and the solution to the "German problem." Topics of broad strategic importance included the development of a joint nuclear force under NATO. The US also worried about the implications of its role as the bulwark of the international financial system, an issue that was to reach a climax in the decade to come. These issues were highlighted by the emergence of French president Charles de Gaulle as a champion of both French national grandeur and European political resurgence and a growing resentment in some parts of Europe towards US hegemony. Compounding this development was uncertainty over the political role of the new European institutions and of their commitment to open markets.

Agriculture was a small but sensitive part of this broad transatlantic agenda, and often engaged political leaders out of all proportion to its importance. Why were the US and the countries of Western Europe not able to resolve some of these agricultural issues at a time when high-level political matters were in play? And why did the EEC develop a defensive posture in agricultural trade matters that made any compromise difficult? This chapter attempts to trace the main conflicts between the US and the EEC over the period 1957, when the Treaty of Rome was signed, to 1972 , on the eve of a massive shock to the world economy discussed in Chapter 2. The structure of this chapter is: to introduce the context (both political and economic) in which agricultural conflicts arose; to suggest the underlying causes of the conflicts as a function of fundamental differences in policy and politics superimposed on structural and market differences; to discuss the conflicts themselves as evidence of dysfunctional transatlantic relationships; and to conclude with some of the consequences of the trade tensions for other aspects of political and economic discourse.

\section{THE POLITICAL CONTEXT}

The rebuilding of Western Europe as a buffer to contain Soviet expansion and to bolster the liberal economic and trade system was among the main goals of the Truman administration in the immediate post-war 
period. ${ }^{2}$ The Marshall Plan injected about $\$ 13$ billion into the economies of Western Europe from 1948 until 1951. The funds were administered by the Organisation for European Economic Co-operation (OEEC), which brought together representatives from all the eligible recipient countries. Congress agreed to the financial outlay as a way of making sure that employment picked up rapidly in Europe and that this would halt the spread of socialism. Though opinions differ as to how much of a role the Marshall Plan funds themselves played in the reconstruction of the continent, the establishment of institutions that encouraged and indeed necessitated cooperation set the tone for the impressive steps toward integration of Western Europe over the following decade.

On the issues of defense and security, somewhat less comity was achieved. NATO, born in 1949, offered the vehicle for transatlantic cooperation in this area. ${ }^{3}$ But the US insisted that NATO be firmly under American control, and this encouraged European alternatives. A plan for a European Defence Community (EDC) was developed (the Pleven Plan) with the support of Jean Monnet, the chief architect of the European Coal and Steel Community (ECSC), and the EDC eventually attracted the endorsement of the Truman administration in the US. ${ }^{4}$ The Eisenhower administration, taking office in 1953, was persuaded that the EDC could be the basis for a European army that would be established within NATO to take the burden of maintaining post-war borders. However, the French National Assembly eventually rejected the EDC in 1954, and the defense arm of European integration gave way to plans for a further initiative focusing on economic integration. The political control and financial burden of NATO was to remain a discordant topic in the transatlantic relationship for the next three decades.

The Eisenhower administration also supported the economic integration plans of Monnet and the French foreign minister Robert Schuman, culminating in the signing of the Treaty of Rome in March 1957 giving birth to the EEC. The formation of the EEC was hailed in the US as a major step towards the stability of Western Europe. The US held the

\footnotetext{
2 For a brief account of transatlantic relationships over this period see Peterson (1996).

3 The first Secretary General of NATO, Lord Ismay, described the role of NATO in undiplomatic terms: it was to "keep Russians out, the Americans in, and the Germans down."

4 The Treaty of Paris, setting up the European Coal and Steel Community, was signed in April 1951, with Jean Monnet as its first president. It became a useful model for the administration of the later European Economic Community. The other European body that was set up in this period was Euratom, an agency devoted to the peaceful use of nuclear power. The three treaties were consolidated in the Merger Treaty of 1965. The name "European Communities" was used for a time before being shortened to the European Community (EC).
} 
view that the UK should play a full role in the process of European integration. The UK did indeed participate but with a somewhat detached view of the discussions in the light of the need to keep the interests of the Commonwealth in mind. ${ }^{5}$ Indeed, the UK had been promoting a less "supranational" form of integration based on the OEEC model, and had been wary about weakening the British Commonwealth by giving preferences to its European neighbors. Commonwealth preferences included the importation of agricultural commodities from Canada, Australia, New Zealand, South Africa and Ireland. Imports from the Caribbean and former African colonies added an additional complication. So the inclusion of agriculture in the plans for integration caused the UK particular problems. However, the UK acted in the belief that it had established a "special relationship" with the US that would overcome any minor differences in approach to European integration.

France was at the same time a leading protagonist for European integration (particularly as it represented the binding of Germany into the institutions and markets) and the most difficult partner in the discussions. Part of that was a reluctance to share sovereignty and part was a reflection of domestic and local problems of an economic and political kind. Indeed successive French governments were consumed with the problems in North Africa from 1954 until 1962, when President de Gaulle gave Algeria its independence. A plan for a European political community (the Fouchet Plan) sponsored by the French in 1961 was abandoned the next year. However, France and Germany did come to an agreement in January 1963 (the Élysée Treaty on Franco-German cooperation) that aimed at overcoming the historical experience of tensions between the two countries by stipulating a close coordination of their policies, including their approaches vis-à-vis both the US and the Soviet Union. ${ }^{6}$

The US was still exploring ways of cementing the fragile Atlantic relationship. President Kennedy outlined a "Grand Design" for a "concrete Atlantic Partnership" in July 1962, based on a "declaration of interdependence" with a united Europe (Peterson, 1996, p. 36). The fact that the unity of Europe was so fragile was being demonstrated by French intransigence. But the US Congress was beginning to see that such a partnership would involve both concessions on trade and loss of absolute control over

\footnotetext{
5 Winston Churchill's famous call for a United States of Europe is widely interpreted as referring to Continental Europe, excluding the UK.

6 After the treaty had been negotiated and before it was ratified, the German chancellor Adenauer annoyed de Gaulle by adding a preamble confirming the close ties between Germany and the US and Germany's interest in having the UK join the EEC. For de Gaulle, an important aim of the Élysée Treaty was to strengthen Europe's position vis-àvis the US.
} 
military decisions. As anti-Americanism rose in Europe, so skepticism took hold in the US. The Kennedy Round of GATT negotiations was in large part a way of saving the vision of interdependence through a resolution of the trade issues posed by the formation of the EEC - and by its plans for a Common Agricultural Policy (CAP).

The resolution of the German problem and the Soviet menace was a task for NATO. The issue was how to bolster European defenses against the Soviet threat and integrate West Germany into the alliance. Once again, the key to such policies lay in Paris. De Gaulle secured his place on the international stage in 1963, when he rejected the US proposal for a NATO nuclear command and (on the same day) declared his opposition to the entry of the UK into the Common Market. ${ }^{7}$ French nationalism had for the moment trumped both European integration and Atlantic unity.

Frustration in the US with European indecision and lack of cohesion was matched by increasing domestic problems of an economic, social and political nature in the US. By the mid-1960s the US public were becoming disenchanted with the military operations in Vietnam, and the social fabric began to fray with the violent protests over civil rights. Later in the decade major changes were introduced in social programs, and legislation for the Great Society was enacted. Concern with the Soviet political incursions into Central and Eastern Europe kept the old continent on the radar screen, but the enthusiasm of the 1950s had been replaced by a weary acceptance of Europe as a somewhat unreliable partner in the design of future global institutions. The withdrawal of France from the operational part of NATO in 1966 confirmed these doubts, and the development of a protectionist agricultural policy for the EEC played into this sense of frustration.

\section{THE ECONOMIC CONTEXT}

Economic trends and crises played a significant part in the post-war development of the transatlantic relationship. The US had emerged from the war as the pre-eminent economic power and during the 1950s established itself as the richest market, the major source of investment funds, the guarantor of economic stability, the locus of technological innovation and the leader in the development of the trade and monetary systems. Europe at that time was preoccupied with domestic economic problems, managing

7 Coppock (1966, p. 2) suggests that January 14, 1963 may have been one of those pivotal days in history: it certainly changed the course of US-European relations for the next decade. It also marked the first anniversary of the CAP. 
its balance of payments, and searching for growth amid competing claims for social programs. To allow the US to behave as the hegemon was both convenient and acceptable. However, by the end of the 1950s the strength of the US economy as the stabilizing force in the western world began to show signs of faltering. The early years of the 1960s saw a major reversal of economic fortunes. Shonfield points to the characteristic feature of this period as being "marked by a reversal of [the] economic relationship between the US and the rest of the Western world brought about by the chronic deficit in the US balance of payments" $(1976$, p. 3). The deficit had existed for much of the previous decade in part as a reflection of the dollar shortage and the perceived need to inject liquidity into the world economy and exacerbated by the efforts of the US to spend more abroad to mitigate this condition. But the drain on the US currency was seen as a part of the problem rather than the solution. Indeed, the Eisenhower administration took some unusual steps in the fall of 1960 to curb the outflow of foreign exchange, including reducing the spending of US servicemen in Europe (Shonfield, 1976, p. 3).

The payments imbalance was not the only sign of economic weakness. The US economy at the beginning of the 1960s was also growing at a sluggish pace, and unemployment was high relative to the economic "miracles" visible in West Germany and Italy. Even France, with all the political turmoil, grew steadily over this period. The UK, the co-manager of the trade and monetary systems in the post-war period, offered no help to the US, as slow growth and payment imbalances gave the successive governments little scope to deal with pressing social and economic issues. The problems with the pound sterling, a reserve currency in the monetary system, were accumulating, culminating in the devaluation of the pound in 1967. And the fact that the UK found attractive a wide free trade area in Europe and had distanced itself from the EEC made it a less reliable partner in international hegemonic ventures. Indeed, a concern in Washington at that time was the division of Europe into two trading blocs, eroding the "non-discrimination" principle of the GATT by creating new preferences, disturbing trade patterns and affecting investment plans. And, of course, the US would lose what it saw as the liberal and moderating influence of the UK when the EEC was making decisions on trade.

The outflow of investment capital from the US to Europe was undoubtedly a significant benefit as the economies moved from the period of reconstruction to that of growth. But it also played into the general feeling among Europeans that Europe needed to maintain its cultural identity. The success of the 1967 book by Jean-Jacques Servan-Schreiber, Le Défi Américain, reinforced the feeling that the US dominated the areas 
of technology, management and research and rekindled the idea of a unified Europe able to meet the American Challenge.

Meanwhile the economic troubles in the US continued to mount. It had become by the late 1960s a recurring complaint by the US that the Bretton Woods monetary system precluded the devaluation of the dollar and systematically led to the overvaluation of that currency. ${ }^{8}$ The monetary crisis came to a head in August 1971 when President Nixon delinked the dollar from gold. ${ }^{9}$ Shorn of the gold guarantee the major currencies floated to find new exchange rates more in line with competitiveness and economic performance. ${ }^{10}$

\section{DOMESTIC FARM POLICY DEVELOPMENTS}

With this context of transformative global and regional political and macroeconomic developments in the late 1950s and the 1960s in mind one might be inclined to assume that agricultural matters, and any potential tensions across the Atlantic that could conceivably result from divergent farm policy trends in the US and the EEC, cannot have had more than marginal significance. Moreover, differences among domestic farm policies need not have necessarily impaired good transatlantic trade relationships. But the concepts behind such policies and in particular the notion of the role of international trade proved to be so different that domestic farm policies emerged as trade irritants. So a brief account of the development of these policies in the US and the EEC over the period of the 1960s is necessary to the understanding of the trade conflicts that arose at that time and those that were to bedevil transatlantic relations for decades to come.

\section{Developments in US Farm Policy}

The era of significant government activity in agriculture began in the US with the policies adopted in the Great Depression of the 1930s. The administration of Franklin D. Roosevelt introduced the Agricultural

\footnotetext{
${ }^{8}$ The monetary system of the time has been labeled a "dollar exchange" regime, with the US maintaining a dollar price for gold and other currencies being tied to the dollar. A dollar devaluation would have been technically possible, but the assumption was that all other countries would follow, thus negating the impact.

${ }^{9}$ In addition the US imposed a 10 percent tariff surcharge: this was later removed at the time of the Smithsonian Accord in December 1971.

${ }^{10}$ The UK was in balance of payments trouble after 1964 and finally devalued sharply in 1967: the pound sterling, the second leg of the post-war currency edifice, was therefore of little use in the search for international stability.
} 
Adjustment Act (AAA) of 1933, which provided for widespread support for government intervention in agricultural markets. The AAA introduced supply control as a way of maintaining market prices. Section 22 of that Act authorized quotas and tariffs on imports when they threatened to undermine domestic supply control programs. Under the New Deal, agricultural prices were to be maintained by an agency, the Commodity Credit Corporation, that could give loans to farmers upon putting a crop into storage as collateral (Orden et al., 1999, p. 21). ${ }^{11}$ The loans could be paid back when the crop was sold, or farmers could simply forfeit their crops to the government. Such "non-recourse" loans became the most visible and popular part of implementing the AAA and have to the present retained their role in farm price support. The supply control activities of the AAA led to 35 million acres (about 12 percent of arable acres) taken out of production in 1934. The Act was reauthorized in 1938, and support prices were tied to "parity" with those that existed before World War I. Support of farm and commodity organizations kept the depression era programs in place and fostered the development of a powerful "farm lobby." By the time of World War II there were price supports for 166 commodities and Commodity Credit Corporation (CCC) loans were available for 20 of these (Orden et al., 1999, p. 54). Congress set the price levels at 90 percent of parity for many of these products.

The US emerged from the war as a major producer of food and feed grains, though with export markets hard to find. The booming post-war domestic economy increased wages in the non-farm sector and drew workers off the land. As a consequence, US agricultural policy focused in the 1950s on the twin problems of surplus disposal (particularly wheat) and the apparent income gap between rural and urban households (the "farm problem").

Successive Agriculture Acts rang the changes between supply control, two-price systems, flexible parity pricing, resource retirement and direct payments. The 1949 bill introduced price supports for dairy products and potatoes and confirmed the commitment to maintaining 90 percent of parity. ${ }^{12}$ In 1954 the Farm Bill lowered parity levels and introduced a Conservation Reserve Program (Soil Bank) that kept up to 10 percent of land idle in the next two decades. The same year saw passage of the main food aid legislation (PL 480) that authorized sales of surplus products for (local) soft currency: in 1960, 70 percent of wheat exports were sold on a

${ }^{11}$ As these authors point out, the loan program was originally intended as a temporary device until the supply control mechanism could be introduced.

12 The 1949 Agriculture Act has remained in place ever since as "permanent legislation": subsequent Farm Bills have been time-limited amendments. 
non-dollar basis. ${ }^{13}$ By the time of the 1961 Act wheat support prices were 50 percent above world market levels (Orden et al., 1999) and stocks held by the CCC were steadily rising.

The Kennedy administration favored supply management to reduce stocks and cut surpluses. The 1961 Feed Grains Bill paid farmers to voluntarily idle corn land, and this was followed up in the feed grain provisions of the 1962 Farm Bill, which introduced deficiency payments for feed grain farmers to compensate for the drop in loan rates toward the world market level. An emergency program introduced in 1962 idled 27 percent of previously planted acres. The 1962 bill also mandated a referendum among wheat farmers that provided them with a stark choice between mandatory supply control coupled with marketing certificates for domestic use of wheat and a sharp cut in prices with no mandatory supply control. The wheat farmers preferred their "freedom to farm," and a new wheat program was introduced in April 1964, based on voluntary acreage reductions compensated by certificates redeemable by the $\mathrm{CCC}$ on wheat used for domestic consumption.

A major step was taken the next year on removing some of the incentives for overproduction. The 1965 Food and Agriculture Act set loan rates at around world price levels for wheat and other program crops and introduced deficiency payments as a partial compensation for the price cuts. ${ }^{14}$ Crop idling programs were also continued on a voluntary basis, and an average of 54 million acres was held out of production over the period 1965 to 1969 (Orden et al., 1999, p. 65). In the context of worsening economic conditions an attempt was made by the Nixon administration to reduce prices in the 1970 Farm Bill. However, Congress insisted on continuing cash payments to producers of the major program crops. "Direct payments remained above 20 percent of the total net farm income in the early 1970s, and sixty two million acres were idled in 1972" (Orden et al., 1999, p. 67). The budget cost of the programs rose in absolute terms but was overshadowed by rapidly increased payments for other domestic and foreign policies.

How much did the internally focused and muddled state of US farm policy enter into the tensions with Western Europe? Clearly there was little enthusiasm in Congress for ensuring that its farm policy was in line with its foreign policy - a disconnect noted by D. Gale Johnson a decade before (Johnson, 1950). With no consistent policy the US gave the impression to

\footnotetext{
13 This outlet for surpluses was to prove temporary. New varieties of wheat and rice were being developed that would over time reduce the need for food aid for the Indian subcontinent.

14 The same step was to be taken by the EU 30 years later.
} 
the new EEC that it was an opportunistic trade partner willing to defend domestic interests without regard to the broader objectives of transatlantic relations. Indeed, the US was behaving as a typical "hegemon," seeking to keep others to a set of rules but not heeding those rules itself. ${ }^{15}$

\section{Development of EEC Farm Policy}

Farm policies of European countries in the 1950s were disparate in objectives and instruments, reflecting the very different conditions in the various states. The UK maintained a relatively open market for farm products, particularly for imports from the Commonwealth. France considered itself a natural exporter of farm products and saw Western Europe as a growing export market. The Dutch and the Danes continued to specialize in livestock products based on imported feeds, as they had since the nineteenth century, and also saw their role as exporting these products within Europe. West Germany, which had embarked on a more protectionist approach to agricultural policy in the last quarter of the nineteenth century, attempted to control grain markets so as to keep domestic producer prices high. Much of the best agricultural land was in East Germany, and small farms dominated West Germany. These national policies posed no immediate threat to the US agricultural trade interests.

This situation changed in the early 1960s as the decisions taken in Europe on the incorporation of agriculture in the new EEC began to cause concern abroad. Thus the main focus of transatlantic tensions in the 1960s over agriculture was on the establishment of the CAP. The two critical features were its instrumentation and the level of prices established under the policy. The choice of protective instruments (variable levies and export restitutions) for the main cereal products, with similar measures for livestock products, virtually guaranteed tensions with external suppliers. The level of support prices was determined by internal considerations, with little relation to world market conditions.

This may have been unsurprising, given the serious difficulties of agreeing internally on a common policy among the member countries of the newly established EEC (Germany aiming at a considerably higher level of agricultural protection than France). Founding members had long-established and politically sensitive domestic agricultural policies (Tracy, 1989) animated by compelling considerations of farm income stabilization and support, vitality of rural areas and food security. In

15 This is in distinction to a "leader," who obeys the rules as an example to those who are being led. 
addition, shortages of foreign exchange made governments keen to expand domestic production even if costs were somewhat high.

The CAP emerged slowly over a period of four years. ${ }^{16}$ The Treaty of Rome mandated the inclusion of agriculture in the common market (Article 38), thus ensuring that individual members could not use trade controls on internal EEC trade after the transition period. The treaty included the provision for a Common Agricultural Policy, with the objectives (listed in Article 39) of ensuring a "fair standard of living" for the agricultural community through productivity increases and the provision of supplies to EEC consumers at "reasonable prices." The means to achieve these objectives was not specified in the treaty. Member states were obliged to complete the establishment of the CAP by the end of the 12-year transition period to a Common Market. Article 40 of the treaty stipulated the "common organization of markets," but offered three alternative options for implementing it: common rules for competition; a coordination of national market policies; or a common European market policy. It also foresaw the possibility of creating a fund to finance this activity. The nature of the common organization of markets was to be debated by member states and selected stakeholders at a conference, held in Stresa in July 1958.

One key aspect of the debate at Stresa was between "the French delegation which advocated drawing up a balance sheet of needs and resources in order to determine what part of requirements should be satisfied by domestic production" and the Dutch delegation, which preferred the trade pattern to be determined in the marketplace as a result of policies chosen (Tracy, 1989, p. 252). ${ }^{17}$ The conference did not come to any firm conclusions but provided the basis for the formulation of specific proposals by a debate within the Commission in the following year.

The first proposals for the common market organizations were circulated by the Commission in 1959, for discussion with other EEC bodies, and the revised proposals appeared in June 1960. ${ }^{18}$ This document

16 The history of the formation of the CAP is told at length in Tracy (1989). Economic studies of the CAP are discussed in Josling and Swinbank (2013). As with much of the architecture of the EEC the main decisions depended on an agreement between France and West Germany. An important part of the bargain in the case of the CAP was that access for French farm products to the German market was exchanged for access for German manufacturing products into France. Indeed, the CAP was seen by many as a policy for French farmers financed by German money. In reality, German farmers became major beneficiaries of the policy.

17 Tracy also notes that the West German delegation stressed the importance of developing trade with third countries.

18 Under the Rome Treaty the European Commission had the sole right of initiation of legislation. Legislative proposals had to be sent to the Economic and Social Committee and 
indicated the instruments chosen to maintain prices on the internal market. The proposals for common market organizations included, for the main products, the establishment of target and threshold prices and the use of variable levies on imports from third countries (and on intraEEC trade during a transition period). Exports from the EEC would, if necessary, attract export "refunds" (a euphemism for export subsidies). The Council created a Special Committee on Agriculture (SCA) to prepare future Council decisions on agriculture, and this body negotiated details of the plan with the Commission. ${ }^{19}$ The Council finally accepted the substance of the Commission's proposals in December 1960. The plan was to apply the levy system in the first instance to cereals, sugar, pigmeat, eggs and poultry, and the Commission was asked to submit specific proposals for cereals (and by extension the cereal-based livestock products) by the market year 1961/62 (Tracy, 1989, p.254). However, the debate on the individual commodities proved time-consuming. The year of 1961 was devoted to preparation and debate of the implementation of the CAP, with draft regulations being submitted for individual commodity sectors. The Council finally approved the package on January 14, 1962. ${ }^{20}$

The 1962 package defined the method of support for the main commodities based on the Council's decision of December 1960, employing a variable levy tied to a threshold price but including opportunities for intervention in the market by national agencies to support the market floor. ${ }^{21}$ Exports would be subsidized by the difference between the domestic intervention price and the world market price. ${ }^{22}$ Though the cereals regime was the centerpiece of the common market organizations, arrangements for other commodities were important. The cereal-based livestock regimes (pigmeat, poultry and eggs) were based on the cereals regime with an additional element of protection of the "value added." The dairy regime also

the European Parliament for comments. The ultimate decision would be the province of the Council of Ministers from the member countries.

19 A body to prepare for Council decisions in other areas, made up of permanent representatives from the member states (COREPER), had already been established. The separation of the preparation of Council decisions on agriculture and other issues may have had the impact of making policy coherence more difficult.

${ }^{20}$ In order to comply with the timetable for moving to the second stage of the EEC transitional period, the clock was "stopped" and the date of the Council decision was recorded as December 31, 1961. The French government (supported by the Dutch) had been unwilling to move ahead with the establishment of a common commercial policy unless agricultural policy was agreed.

${ }^{21}$ The threshold price and the intervention price were each (notionally) tied to the target price, representing the price at which goods should be sold in the domestic market in the areas of greatest deficit.

22 These payments were known as "refunds" or "restitutions": the label "subsidy" was avoided for years by the Commission. 


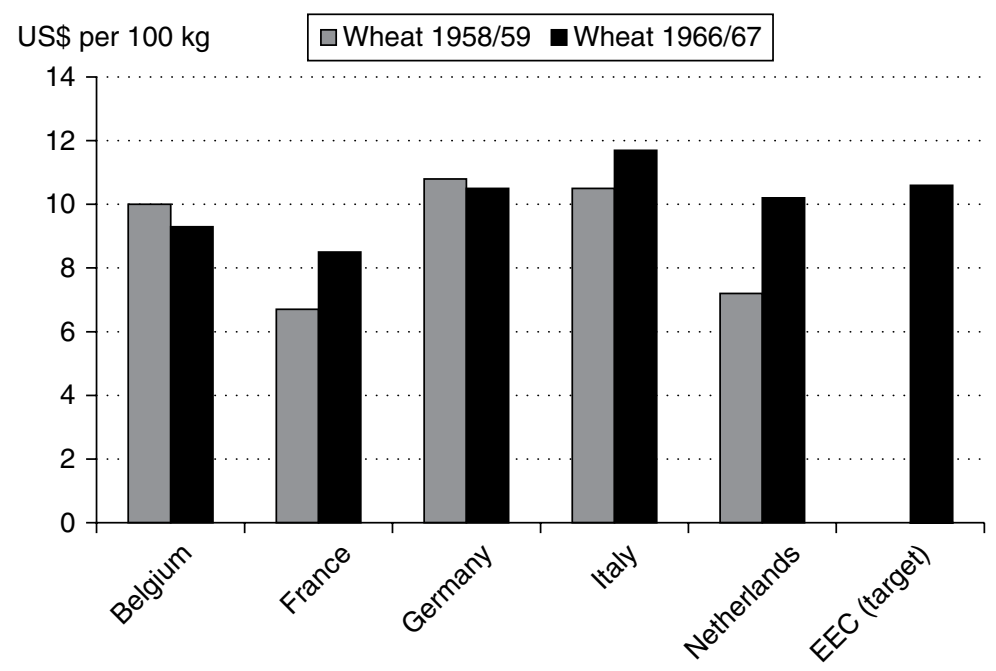

Source: Marsh and Ritson (1971).

Figure 1.1 Wheat prices in EEC member states, 1958/59 and 1966/67, and EEC common target price for 1967/68

used target prices but operated through import levies and market intervention purchases for the principal milk products. Both this regime and that for rice were agreed in 1964, followed by olive oil in 1966, sugar in 1967 and wine in 1970. Only the regime for fruits and vegetables (agreed in 1966 and reinforced in 1968 and 1970) provided more flexible support to allow market conditions to be manifest (Tracy, 1989, p. 256).

The difficulty in agreeing to common prices that would apply at the end of the transition period provided plenty of drama in 1963. The price-level decision was to be taken by July, and that allowed the French to agree to an opening position in the Kennedy Round of GATT negotiations (discussed below). The problem of prices centered on the high levels of cereal price that had been established in West Germany, and in particular the wheat price (Figure 1.1). The high level of protection in that country corresponded, in part, to the poor farm structure mentioned above. ${ }^{23}$ As

23 Illustrating the intensity of the German debate was the reaction by the farm organizations to the publication by the Commission in 1962 of a study by eight academics who calculated the rate of outflow of labor that would be needed to maintain the growth in farm incomes. The German professors who had taken part in the study were denounced publicly as threatening the existence of hundreds of thousands of German farmers (Tracy, 1989, p. 261). 
exporters, France and the Netherlands had low prices in the lead-up to the CAP. ${ }^{24}$ These two countries pressured Germany to arrive at a commitment on common prices but succeeded only in achieving an agreement to freeze prices at current levels.

The debate on price levels continued to consume the EEC during 1964, with France threatening to leave the Community if the regime for cereals was not put in place by the end of the year. In December the German minister for economic affairs (in the temporary absence of the minister of agriculture) agreed to a reduction in the German wheat price in exchange for a delay of a year in the implementation of the change and for compensation for German, Italian and Luxembourg farmers for the price cut. The crisis had been resolved, at least temporarily, and the plans for establishing a common price were back on track.

The transition to common prices was finally completed in 1968, and the common market regimes took over from national farm support policies. However, this peaceful state of affairs was to change abruptly with the exchange rate realignments of 1969 . The EEC had initially made the assumption that setting farm support prices could be done on the basis of a "unit of account" (UA) equal to a dollar. It was even suggested that this in itself would preclude exchange rate changes. But in 1969 the exchange rates of the franc and the Deutsche Mark (D-mark) with the dollar proved untenable, and the franc was devalued by 11 percent and the D-mark revalued by 9 percent. This caused a rethinking of the operation of the CAP price supports, and for the next two years the prices of the same product in France and Germany differed significantly. Border tax adjustments had to be introduced to prevent flows of commodities to take advantage of arbitrage. ${ }^{25}$

The other aspect of the CAP that caused some controversy over its first decade was the method of financing the policy. That the CAP would be financed by the EEC as a whole was not in doubt, but the way in which the funds should be raised was not so clear. The Commission had suggested that the income from levies on third-country imports be used to finance the policy. But that would have left Germany and the Netherlands to foot the bill. A compromise was agreed whereby direct contributions, based on a key, would be used initially but be phased out over a few years (Fearne, 1991). The debate on financing became embroiled in the French objections

${ }^{24}$ Italy also had low prices relative to other countries in the region for feed grains though not for wheat.

25 This problem of exchange rate changes in a regime of fixed common prices was to recur in the early 1970s, as is described in Chapter 2, where the "green money" system introduced by the EEC in that context is discussed more fully. 
to the issue of majority voting as a counterpart to EEC financing of the CAP and the subsequent "empty chair" policy in the summer of 1965 that left the French place in the Council vacant. The Luxembourg Compromise forged in the spring of 1966 addressed the issue of majority voting by giving member states the opportunity to reserve certain issues as of vital national importance and thus give them an effective veto on these matters.

The decade closed on a brighter note. A Conference of Heads of State and Government in The Hague in December 1969 confirmed the willingness of member states to move towards monetary union, to agree to reopen enlargement discussions (with the UK and other countries) and to create the EEC's "own resources" from levies and tariff revenues (and later from a notional one percentage point of value added tax) to pursue common policies (including the CAP). A change in leadership in France had ended seven years of confrontation and obstruction and left the way open to thinking on a longer-term basis about the future of European agriculture - and what to do about emerging surpluses of wheat, dairy products and sugar.

The main proponent of such thinking had been Sicco Mansholt, a former Dutch farm minister who had chaired the Stresa conference and served as the first commissioner for agriculture. In 1968 the Commission released a document that became known as the Mansholt Plan. ${ }^{26}$ This document addressed the issue of the structure of EEC agriculture, in particular the need to consolidate holdings if the sector was ever to become competitive. This would require a redirection of funds away from price supports and the export of commodities with subsidies toward structural aids that could help farmers adjust. Such wisdom fell on deaf ears among the farming community, and Mansholt had to be content with three mild "directives" on structural reform passed in 1972. ${ }^{27}$ Mansholt's tenure as agricultural commissioner ended with his bold attempt to redirect the CAP in tatters.

26 The formal title was the "Memorandum on the Reform of Agriculture," published in December 1968. Mansholt predicted an imbalance in agricultural markets stemming from a focus on price support and a neglect of structural policy instruments. But he drew the ire of farm groups by estimating that 5 million farmers would have to leave the land to make room for larger farms (modern agricultural units). In hindsight, the reduction in the workforce and the consolidation of holdings took place at a more rapid pace than he had considered necessary. Indeed, ironically, in later years Mansholt came to be a champion of small-scale farming.

27 The status of a directive is that it has been agreed at the EEC level but requires national legislation to implement. Thus countries that were against the structural programs could delay their implementation. The directives dealt with three issues: the modernization of farms; the encouragement to farmers to leave the land; and the provision of socioeconomic guidance and training for those engaged in agriculture. 
The outcome of the interminable CAP debates in the 1960s was not received with enthusiasm across the Atlantic. There emerged a general concern in the US that the European market for farm product exports from the US would continue to shrink. Was this an inevitable consequence of EEC farm output growth no matter what policy the EEC had chosen? Perhaps it was, but, had it just been "normal" market development there would have been less grounds for policy tensions.

\section{CAUSES OF TRADE TENSIONS}

The tensions that built up in the 1960s, and that made the Dillon Round and the Kennedy Round so contentious, arose from differences in political philosophy, agricultural structures and administrative cultures. There were however some underlying similarities that made the conflicts more apparent. Neither side of the Atlantic fully understood or trusted the other, but both were convinced that their livelihood and destiny were entwined. The brief account that follows highlights some of the structural and political differences that appear with hindsight to have led to trade tensions in the area of agriculture and food.

\section{The Structure of Agriculture}

The agricultural tensions between the US and Western Europe that emerged in the 1960s in part reflected the different conditions of farming on the two sides of the Atlantic. US and European agriculture in the postwar period had very different structures and faced different problems. US agriculture had been spared the impact of wartime devastation and had benefited from strong post-war demand for cereals. Infrastructure had been improved during the war. By contrast European agriculture was badly damaged by hostilities and needed time to recover to pre-war output levels. Imports of basic farm products grew, but the shortage of foreign exchange and subsequent protectionist policies slowed their growth. In addition, memories of food shortages played a role in the decisions to boost domestic cereal production in Western Europe.

In some respects the agricultural structures had been diverging since the 1870s. The westward expansion of agriculture in North America and the homesteading policies provided for a farm structure that was able to take advantage of technical progress in the twentieth century, involving the use of tractors, fertilizer, and improved seed varieties. By contrast Western European agriculture (with the partial exception of the UK) remained a victim of land fragmentation and traditional methods of farming. In many 
parts of Europe, land fragmentation had resulted from a long history of inheritance customs and law, while in the US the more recent settlements had created larger holdings. This difference in farm size was compounded by the fact that small farms predominated in the parts of Europe where jobs were scarce and yields were low, such as in central France, southern Germany and the Mediterranean region. By contrast, in the US small dairy and fruit farms in New England benefited from the proximity of affluent urban areas and relatively high yields. Southern farming had focused on cash crops (cotton, tobacco, rice, peanuts and sugarcane) for which the market was expanding. Cereals and oilseeds, along with cerealbased livestock, were generally produced on farms larger than those in Europe, particularly marked in cereal-growing areas such as the Great Plains. In the US the flow of labor from agriculture led to consolidation of holdings. In much of Western Europe the corresponding adjustment was delayed by the difficulties of consolidating fragmented holdings and by widespread concerns over the depopulation of the countryside.

Geography and climate also play a part in defining the different farming structures. Agriculture in Western Europe enjoys a degree of diversity that reflects a wide variety of soils and climatic conditions, ranging from the Mediterranean regions to the Arctic Circle. ${ }^{28}$ The US exhibits an even wider range of climatic zones and soil types, with more sub-tropical areas and more dry deserts. However the main differences vis-à-vis Europe are in the vast Mid-West of the US, where wheat, corn and soybeans along with corn-fed livestock are grown on large farms with adequate size for mechanization. But a functioning trade system should take advantage of these differences to the benefit of both importers and exporters.

\section{Differences in Farm Politics}

Though many of the policy differences can be explained by structural and market balance elements, other factors undoubtedly played a part in the deteriorating tone of transatlantic agricultural relationships. These include: political strength of agricultural lobbies, unwilling to allow negotiators to search for solutions; the legislative structure that granted veto power to rural legislators (in the US) and agricultural ministers (in Europe); and the role of farming in the fabric and culture of society.

The political environment in which agricultural policies are made and administered can have a significant impact on the potential for conflict.

\footnotetext{
28 A fuller discussion of the structure of agricultural production in Western Europe can be found in Josling (2009).
} 
There were some sharp differences between the US and the EEC in the formation and administration of farm policies over this period, and several of these appeared to prolong the conflicts. One such difference was the influence of commodity groups on farm policy. In the US, in part as a reflection of the instrumentalities of the 1933 Agriculture Act, policy was much influenced by trade associations representing the interests of specific commodities. The groups representing the grains and oilseed sectors, along with the cotton, peanut, sugar and tobacco growers (and processors), each had individual specific interests but were able to combine when farm legislation was being discussed to form a formidable political force. These groups had good relations with members of Congress and particularly the Agricultural Committees (of the House and the Senate) and the corresponding Appropriations Committees, which have control of spending that is not mandatory. The third side of the "iron triangle" as it is often called is the set of departments that have to administer the programs. In the case of the US, the authority of the United States Department of Agriculture (USDA) has been closely maintained by Congress, and an adversarial position is often taken to the "interference" of other government departments. In the case of trade, this takes the form of officials from the Foreign Agricultural Service (FAS) of the USDA, the agency with a mission to promote agricultural exports, taking the lead in the trade negotiations when agricultural issues are being discussed.

The EEC has a somewhat different political environment and administrative structure. Commodity groups have a limited place within the political decision making in most member states. More important are general farm organizations that coordinate the interests of the farmers and exert sector-wide pressure on policy makers. ${ }^{29}$ Trade associations operating at the European level have evolved in recent years, but in the formative stages the main actors were the member states themselves as represented by their ministers of (and for) agriculture, typically politicians from an agricultural background and friendly towards the farming industry. The national balances of costs and benefits are reflected in Brussels by the Council of Ministers (of agriculture for CAP issues). The Commission, in addition to having executive responsibilities, is the sole initiator of legislation. And the Commission's proposals have to be agreed by the Commission as a whole (the College), meaning that the influence of the agricultural commissioner is not unlimited. And since the Commission is responsible for trade

${ }^{29}$ General farm organizations in the US also played a role in policy making. The Farm Bureau Federation was generally market- and export-oriented, while the smaller National Farmers Union was more focused on the problems of small farmers. 
negotiations (following a mandate from the Council) the reconciliation of differences is undertaken at various stages in the process.

These differences should not however be exaggerated. The overwhelming factor determining the outcome of trade negotiations and conflicts in both the US and the EEC in the 1960s was the ability to sell the package to domestic politicians who had the interests of their rural constituencies in mind.

\section{Diverging Policy Priorities}

These structural and political differences expressed themselves in different policy priorities in the EEC and the US. In the 1950s the US faced surplus conditions for its main crops (in particular wheat, but also corn and soybeans) and devised ways of expanding overseas markets such as through food aid. Such market expansion was a welcome change from the supply limitation policies that were tried in the 1930s. As one commentator put it, "Experience during and after World War II made it apparent that export demand was capable of creating farm prosperity to an extent, and with far less cost and turmoil, than a decade of intensive effort by the Federal government had been able to deliver in the 1930s" (Gardner, 2009, p. 181). Indeed, US agricultural exports did expand, from 4 million tons of foodstuffs in 1935-39 to 19 million tons in 1947-50 (Gardner, 2009, p. 181) as a result of the Marshall Plan and other factors.

As a part of this strategy, the US developed an extensive set of policy instruments for moving food to low-income consumers and to low-income countries. These programs have their genesis in the post-war period of grain surpluses. Food aid was authorized in 1954 under the Agricultural Trade Development Act (known as PL 480): President Eisenhower announced the aim as "to lay the basis for a permanent expansion of our exports of agricultural products with lasting benefits to ourselves and people of other lands." Later, President Kennedy renamed the program Food for Peace and reiterated the significance of food aid as a way of giving a "helping hand to people around the world whose good will and friendship we want." 30 The program had multiple motives and thus multiple friends. Clearly the massive removal of grain from the US market boosted prices and made up for weak commercial demand. Many of the countries that accepted US wheat eventually became major commercial buyers of that product. However, the impact on the recipient countries was more controversial. Food shortages were certainly alleviated and foreign

30 The quotations are from the website foodaid.org. 
exchange saved, but demand for local products suffered as governments found it easier to accept food aid than stimulate domestic production. ${ }^{31}$

The countries of Western Europe did not have surplus grain to give away to foreign governments in the 1950s and raised few complaints against those that did. Their assistance to developing countries was closely tied up with colonial relationships, but this largely entailed providing markets for the export commodities of these countries. However, as surpluses appeared on markets for wheat and dairy products, the EEC also began to take a more active role in providing food aid. In the 1970 s there was a move to "multilateralize" and discipline such aid, through such initiatives as the Food Aid Convention, and the EEC supported this development. ${ }^{32}$

One focus of the agricultural strategy of most European countries at that time was to reduce reliance on imports and restore domestic production, and hence farm prices were held up by import restrictions. This translated into the prices chosen for the CAP, as described below. Thus cost divergences between the US and Europe became translated into policyprice divergences, as levels of protection and support rose in an attempt to meet income goals in Western Europe.

Early manifestations of these differences emerged in the discussions within the OEEC over the integration of the Western European economies in the 1950s. The UK was something of an outlier as regards agricultural prices. As a key part of the Imperial Preference trading system that had been negotiated in Ottawa in 1932, agricultural products from the British Commonwealth had preferential access into the UK market. ${ }^{33}$ This was a crucial difficulty with the inclusion of agriculture in the plans for preferential trade within Europe, largely because of the inevitable adverse impact on trade with the Commonwealth. This in turn led in part to the rejection by the UK of the EEC and the support for the European Free Trade Association (EFTA) (Tracy, 1989). The difference in views between the UK and the other countries of Western Europe over the desirable level of agricultural prices was to have an impact over the years on the direction of the CAP.

31 Over time the food aid program expanded, first to "soft currency" transactions where the country could pay for the food in its own currency, and later to "food for work" and eventually to aid given to charities, which could then sell the grain to raise funds for their own programs (monetization).

32 Over time, the nature of EU food aid has become notably distinct from that of the US, with much higher proportions of the aid being in the form of cash.

33 The Imperial Preference trade system had as its core principle the dictum "home first; Empire second; foreigners last." As might be expected, the US was not enamored of the idea. And the series of bilateral agreements that constituted the system lasted for five years after the Ottawa Agreement and were not subsequently renewed. However, a system of Commonwealth Preferences did persist after the war until the UK entry into the EEC. 


\section{CONFLICTS IN THE GATT}

The US and the UK were intimately involved in the construction of the post-war multilateral economic institutions, including the creation at Bretton Woods of the International Monetary Fund and the World Bank as well as the agenda for the specialized agencies of the United Nations. The development of an institution to assist with the establishment of rules for international trade was not possible at Bretton Woods, though an agreement on a plan for post-war trade policy formed part of the discussions between the US and the UK about the extension of "LendLease" support for the UK economy. The Anglo-American commercial policy agreement laid the groundwork for a wider multilateral convention, and the US State Department released a paper on "Proposals for Expansion of World Trade and Employment" (Irwin et al., 2008, p. 72). A "nuclear" group of 14 countries were invited to meet by the summer of 1946 to discuss barriers to international trade and ways to reduce them. Meanwhile at the UN Economic and Social Council the US proposed in February 1946 to convene a conference on trade and employment in Havana the next year. The US considered the Proposals and the discussion of them to be the best basis for preparing for the Havana Conference. A preparatory meeting in December 1946 achieved broad agreement on the shape of an international convention on trade, and a follow-up meeting in early 1947 firmed up the language. A third preparatory meeting was held in Geneva later that year and included a set of tariff negotiations among a group of the countries involved. Talks on a commercial code of conduct were concluded in 1947: the GATT was largely intended as a way of ensuring that the tariff cutting offers were credible and could not be undone by later actions. As it turned out, the agreement in Havana to set up an International Trade Organization (the Havana Charter) was not ratified by governments, and the GATT proved to be the only lasting contribution of the $1945-47$ discussions on international trade. ${ }^{34}$

\section{Agriculture in the GATT}

The treatment of agriculture in the GATT reflects the place of the sector in domestic politics in the early post-war period. Discussions about the

\footnotetext{
${ }^{34}$ The role of other European countries, besides the UK, was less pivotal. France and the Benelux countries took part in the negotiations that led to the GATT but did not exert noticeable influence. The talks predated the establishment of the Federal Republic of Germany in 1949. Italy played no role in the process. Canada and Australia were active participants, the latter being considered to speak for developing countries.
} 
post-war trade system can be traced to the US-UK talks in 1942 on the Lend-Lease program and the Atlantic Charter (Irwin et al., 2008). At first it seemed that agricultural trade might be treated in a similar manner to trade in manufactures in the post-war economic framework, a position initially taken by the UK. But this proved too controversial. The level of government involvement precluded that action. The US had introduced price supports for main farm products in 1933, and linked these to quantitative restrictions on production and imports. Open markets for imports seemed impossible under such conditions. And the enthusiasm of the UK was ambiguous. By 1944 the British negotiators had abandoned the notion of a full integration and proposed instead a plan for a multilateral convention on trade in agricultural and raw food products that would be appended to the convention on commercial policy (Irwin et al., 2008, p. 53). They argued that control over such imports would likely be needed in the post-war economy: besides, the UK had an empire that supplied it with agricultural products, so lower tariffs on imports from other countries would have reduced the degree of preference that the Commonwealth countries enjoyed. Even Canada, with predominantly export-oriented agriculture, had begun building a raft of parastatal marketing agencies and was not willing to see their effectiveness reduced. ${ }^{35}$ So the architects of the GATT decided to avoid controversy and introduced special treatment for agriculture.

The treatment of agriculture in the GATT proved an inadequate basis for the international discipline of the farm policies of the US and subsequently of the EEC. The drafters of the GATT resolved the issue of countries wanting to keep autonomy for their domestic policies by creating exceptions. The GATT does not in general differentiate trade rules by sector or product group. The GATT referred to all goods trade and thus included agriculture. ${ }^{36}$ Agricultural goods are also not defined in the GATT, but special provisions for agricultural or fisheries products, primary products and commodities are found in several places. These specific provisions each act in the direction of giving national farm policies more scope than domestic policies for other sectors of the economy.

The fact that the GATT prohibited non-tariff trade barriers (import quotas and similar quantitative devices) would normally have hindered the US in its management of markets for dairy products and sugar.

35 However, Irwin et al. (2008, p. 77) note that Canada argued against the Article XI.2(c) exception (see below) when earlier drafts of the GATT were being discussed.

36 This point was emphasized by Hudec (1998), who was correcting the misapprehension that agriculture was not fully included in the GATT rules. The "exceptionalism" of agriculture is discussed in Josling (2010). 
Accordingly - at the insistence of the US - the GATT articles had included a provision (Article XI.2(c)) that allowed quotas if domestic production was also restrained. But even this provision did not go far enough for the US: when Congress insisted that the administration put quotas on imports that threaten domestic programs regardless of whether effective supply control was in place (Section 22 of the 1933 AAA, as amended) the US had to request a waiver from its GATT partners. The waiver, granted in 1955 and renewed annually until it became irrelevant after the Uruguay Round, essentially took major parts of US agricultural policy off the table in the GATT. Other countries took note: with the US waiver in mind countries felt less pressure to respect either the letter or the spirit of Article XI.

The emergence of the EEC posed a different problem for the GATT: the CAP import regime for cereals and (mutatis mutandis) for other products had chosen a variable levy rather than a fixed tariff or an import quota to protect against lower-priced imports, a regime that was effective for avoiding the impacts of prices that would undermine the internal support levels. Understandably it was resented by exporters as frustrating price competition in the EEC market. The clarification of the legal status in the GATT of the "grey area measure" was never fully resolved, and it continued to be a point of contention until elimination of such variable levies was achieved in the Uruguay Round. ${ }^{37}$

Export subsidies had begun to be used in agricultural markets early in the post-war period, and were considered necessary as a way of relieving pressure on domestic markets and sustaining domestic support prices. The restraints on export subsidies (and domestic subsidies that might increase exports) in GATT Article XVI were initially weak: essentially obliging countries to notify other countries that might be affected. ${ }^{38} \mathrm{~A}$ stronger version was introduced in 1955 that banned export subsidies for all but primary goods. For these products the provisions were more lenient, obliging notification as before but adding a requirement that subsidizing countries should not capture more than an equitable share of the market, which though was never defined in quantitative terms. From the point of view of giving legal coverage for agricultural policies this special exemption regarding export subsidies for primary products proved more important than the one relating to quantitative import restrictions.

${ }^{37}$ An additional problem with the variable levy was that it was not constrained by a binding in the same way that a tariff was bound. The EEC sometimes described the variable levy as "an unbound specific tariff." The EEC had unbound all member state tariffs in 1959, and this situation was only changed by the Uruguay Round Agreement on Agriculture 35 years later.

38 At the time it was the US that objected to stronger measures on export subsidies for primary goods. 
The US had until the 1960s been the main country resisting the application of "normal" GATT rules to agriculture. It had an established farm policy and the formidable "iron triangle" of Congressional committees, administration bureaucracies and sector lobbyists to make sure that internationalists in the State Department and the trade ministries did not impose constraints. By the start of the Kennedy administration the attitude was changing. The US began to consider that its interests lay in reducing barriers to its exports, even if it had some defensive positions to protect. This change of heart was emphasized in the message to Congress when asking for passage of the Trade Expansion Act of June 1962. It was no coincidence that this newly aggressive approach to agricultural trade came five months after the decision by the EEC Council of Ministers that established the main provisions of the CAP. The scene was set for a series of confrontations that would last for five years.

\section{The Rise of Transatlantic Trade Conflicts}

Trade conflicts typically arise from rapid shifts in the volume of trade. Either the importing country will look for relief from the pressure of rapidly growing imports or the exporter will complain over restrictions on trade imposed to curb those imports. The 1960s were a time when shifts in trade flows were a frequent occurrence. Which ones caused serious diplomatic tensions and which were absorbed in the general flexibility of investment decisions and employment opportunities may at times seem arbitrary. One early trade conflict was the Chicken War, which simmered for several months as the US complained that the import regime for poultry in the EEC was a serious impediment to trade (see below). However, its importance reached far beyond the rather small value of trade that was involved. The Chicken War became a microcosm of US-EEC trade relations in the area of agricultural commodities, a proxy war for all the more significant trade tensions following the formation of the CAP.

The multilateral framework within which disputes between countries could be arbitrated was itself largely untested. The GATT had been set up in 1947, but the settlement of disputes within the GATT suffered from a lack of legal precision in the agreement and of mechanisms for enforcement. So conflicts were largely bilateral in nature and reflected the interests of the major players. Tensions between the US and the EEC over agriculture dominated the two main trade negotiations in the 1960s, the Dillon Round and the Kennedy Round. Juxtaposed in between was the "Chicken War," the first skirmish in the attack on the CAP. 


\section{The Dillon Round}

GATT discussions on EEC agriculture had started with negotiations in September 1960 that were necessary to compensate suppliers for the impact of any increased tariffs introduced by the adoption of the Common External Tariff (CET) of the EEC. ${ }^{39}$ The impetus had come from the US State Department, following a tour of the non-EEC capitals in Europe by C. Douglas Dillon, the under-secretary, to discuss the ways in which the trade disruption arising from the CET could be managed. The EEC had withdrawn the previous national GATT bindings under a provision (Article XXVIII) that allowed for contracting parties (as GATT members were known) to periodically modify their concessions subject to negotiation with other parties, with measured compensation if necessary. The non-EEC countries in Europe were also concerned that the CET might split Europe into two trade blocs, and were discussing a broader free trade area under the auspices of the OEEC that would include the EEC. The US was cool to that solution, realizing that it would increase the discrimination against US exports. A GATT ministerial meeting in November 1958 to consider the options was disturbed by the announcement from the French government that France would not take part in an OEEC free trade scheme (Curzon and Curzon, 1976, p. 168). This increased the attraction of putting weight on the GATT procedures to obtain tariff cuts from the EEC. It in addition gave the more liberal members of the EEC (Germany and the Benelux countries) an opportunity to argue for lower common tariffs.

There was some urgency in engaging the EEC in tariff talks. The compensatory phase of the talks began in 1960 with the EEC presenting a list of items previously bound by its member countries and calculating the extent to which "internal compensation" had been achieved (as a result of some tariffs declining to offset others that were to be increased). The EEC's submission concluded that no compensation was due, as the CET had been calculated as an arithmetic average (albeit unweighted) of existing tariff levels. The major exception was in the case of agricultural products, where the EEC argued that it had yet to settle the details of the CAP and therefore could not engage in discussions of tariff bindings in this sector.

The Dillon Round moved in some haste to the second "reciprocal" phase, where general tariff cuts were negotiated among all GATT member countries. The US administration had been given negotiating authority by

\footnotetext{
39 The relevant GATT provision is in Article XXIV:6, which requires such discussions in the case of customs unions.
} 
Congress until June 1962, and the EEC's CET was due to be introduced in stages from January 1962. It was agreed that the talks were to be on a product-by-product basis, with requests for tariff changes being met by offers of the importing country. The EEC sent a list of requests to the US that was about five times as long as the list sent by the US to the EEC, and the US offer covered only about one-fifth of the EEC's requests. Though the final outcome was regarded in the US as a net gain for manufactured goods, there were in effect no significant tariff reductions on the part of the EEC. There was however an agreement that the EEC would carry over its "offer" of a 20 percent cut in the CET to a full round of trade negotiations once the US had Congressional authority to improve its own offer.

The US position on agriculture originally was to request from the EEC a binding of ceiling rates not to be exceeded by the variable levies once they were introduced as elements of the common market regimes still to be agreed internally in the EEC. If successful, this request would have at least established some sort of a binding of the EEC's border protection, replacing the bound tariffs that the EEC's member countries had in the past. This appeared so important to the US that it threatened collapse of the negotiations should such ceiling bindings not be agreed by the EEC. However, the EEC refused to accept any such limits to the level of protection achievable by its still emerging agricultural market regimes - and thus avoided binding tariffs in agriculture for the following 30 years. The US then proceeded to argue for guaranteed access into the EEC market based on historical shares. The EEC was not prepared to grant such guarantees but it did agree to a standstill agreement, obliging it not to raise tariffs beyond the level obtaining in September 1962, until such time as the CAP market regimes entered into force. It also confirmed that the US had "unsatisfied negotiating rights" in the sense that any compensation for the introduction of the EEC's (future) new common tariffs still had to be negotiated. The US eventually softened its initial stand on agricultural market access by the end of the Dillon Round in 1962, in part owing to the broader foreign policy objective of supporting the process of European integration. More problematic was the fact that the EEC was not ready for these negotiations: the CAP rules were not agreed until 1962. Understandably, the EEC did not want to be obliged to change its painfully conceived common policy.

The most notable outcome of the Dillon Round was an agreement by the EEC to bind (at zero or low levels) a number of animal feed ingredients, including oilseed meal, manioc and corn gluten. These tariff bindings by the EEC later turned out to cause the problems the EU was to have with "cereal substitutes," and thus the background to the EU's request for "rebalancing" put forward in the Uruguay Round negotiations 
(see below, Chapter 3). Oilseed tariffs themselves were also bound, leaving open the door for the rapid expansion of imports of this product. However, even this outcome proved controversial as the EEC sought to stimulate its own oilseeds sector - and became the focus of the oilseeds dispute that had an important impact on the results of the Uruguay Round (also to be discussed below).

\section{The Chicken War}

The Chicken War was sparked by the establishment of the instrumentation of the CAP regime for agricultural markets in January 1962. As described above, the CAP had been set up in a series of stages, starting from the inclusion of the mandate in the Treaty of Rome (1957) to establish such a policy and the Stresa Conference in 1958 to gather ideas on the appropriate instruments to use in addressing the mandate. The agreement on the principles of the CAP was reached in July 1960, providing the framework for the basic regulations that were to apply to the common organization of markets. By the end of 1961 the Commission had prepared a "package" of regulations that would constitute the CAP, and final agreement on that package was achieved in January 1962.

One part of the package (Regulation 22) related to the specific details of the regimes for products derived from grain such as pork and poultry. In brief, the regime for poultry comprised: a calculated price (the sluicegate price) intended as reflecting the cost of producing chicken at world prices for feed; an "equalization fee" based on the extra cost of feed in the EEC relative to that paid by outside producers; an EEC preference levy, of 2 percent initially but rising to 7 percent, to provide an incentive to buy domestic supplies; and a "supplementary levy" designed to bridge any gap between the world price and the sluice-gate prices. ${ }^{40}$ Besides the complexity of the calculations the system allowed for some creative use of coefficients and conversion rates. As a result of the new regime, the tariff on poultry imports into West Germany increased threefold, from US 4.5 cents per pound to the new EEC levy of US 13.5 cents per pound.

Almost immediately after the poultry regulation had been agreed the US complained about the impact that it would have on its growing poultry exports to West Germany. Trade in chicken and turkey from the US had increased sharply over the period 1956 to 1962 , from 4 million pounds to 152 million pounds (see Table 1.1). US poultry exports to the Netherlands also increased, but by a smaller amount. The West German market had

40 Initially there was also a member state levy based on price differences that predated the regulation, to be phased out as the internal prices were harmonized. 
Table 1.1 US shipments of poultry to West Germany, 1956 to 1962

\begin{tabular}{lc}
\hline Year & Million pounds \\
\hline 1956 & 4.0 \\
1958 & 7.7 \\
1959 & 52.0 \\
1960 & 86.0 \\
1961 & 137.0 \\
1962 & 152.0 \\
\hline
\end{tabular}

Source: Talbot (1978, p. 11).

been carefully cultivated by a grant of food aid: in 1956 a PL 480 Title I grant administered by the USDA allowed the West German government to buy poultry with local currency (the D-mark) to economize on foreign exchange. ${ }^{41}$

US poultry interests were understandably excited by the success of exports of frozen chicken to Europe in general and to West Germany in particular. The Institute of American Poultry Industries (IAPI) set up an office in Frankfurt. New markets abroad would help absorb excess supplies at home. But European poultry production was also increasing, and the West German market was a prize for other poultry exporters, such as Denmark, Hungary and Poland, which also increased exports to West Germany at that time (Talbot, 1978, p. 11). The stage was set for a direct challenge to the newly minted CAP.

The first few months of 1963 saw rising concern about the impact of the CAP on US farm and food exports, and the fate of poultry became a focus. Negotiations on the chicken regime started in June 1963, but the EEC seemed unwilling to make an offer that would be acceptable to the US. The EEC faced many other issues at that time and was reluctant to interrupt the process of building the framework for economic and political integration, just to negotiate on poultry levies. The US prepared for retaliation and developed a list of possible targets for tariff increases. The EEC Council of Ministers held out against the proposals by the Commission to compromise, and the US declined the new EEC offer in September 1963. At that point the decision was made to ask for the GATT arbitration process to resolve the dispute. The EEC agreed that the US complaint

41 The rationale for PL 480, as discussed above, was primarily as a way of exporting grains. But other commodities, such as poultry, could be included as a means of market promotion. 
was fundamentally valid, but questioned the magnitude of the trade damage claimed by the US. The report of the GATT panel was released in November 1963 and found that the EEC had violated the standstill agreement concluded with the US in the Dillon Round and that the US had, as a result, lost $\$ 26$ million of poultry trade. The US accepted the GATT decision on November 21, 1963 (Talbot, 1978).

The US retaliation (technically a withdrawal of tariff concessions) against the EEC was a carefully targeted list of tariff increases designed to draw attention to the violation. The items included: brandy (aimed at France, which had excluded all US poultry on health grounds); "automobile trucks" (pick-ups from Volkswagen of West Germany); and potato starch and dextrine (from the Netherlands). The additional tariffs went into effect in January 1964. The trade impact was small, but the symbolism was clear. The US would attempt to use GATT processes to keep export markets open in the face of the CAP, even if that was harmful to the desired cooperation on broader political issues. President Kennedy was reported to have said to his biographer, Theodore Sorensen, "Is the Grand Alliance going to founder on chickens?"

What was learned from the Chicken War? Could it have been avoided? How much impact did it have on future transatlantic relationships? Obviously the timing was not good for the EEC. The CAP in 1963 was still a work in progress. But the issue of institutional interest was the meaning of the standstill negotiated in the Dillon Round, as a statement of the extent to which compensation for unbinding previous commitments had been satisfied. The US asserted that it had "unsatisfied negotiating rights" arising from the compensation phase of the Dillon Round (see above). The panel did indeed find that the standstill had been violated in the case of poultry. But the US did not manage to make use of those rights in the Kennedy Round that followed. So the lesson that the US took from the Chicken War was that the EEC in developing its own internal policy was not willing to take into account either the commercial interests of overseas suppliers or its obligations to the contracting parties to the GATT. The EEC on the other hand learned that the US was adept at playing the GATT game but that the whole challenge was poorly timed and brought no benefits either to US poultry farmers or to US consumers of the goods targeted for retaliatory tariff increases.

\section{The Kennedy Round}

The relative failure of the Dillon Round led to a further round of trade talks that began in May 1964 (the Kennedy Round). The discussions about this new round started even before the Dillon Round was complete. The "unsatisfied negotiating rights" that had accumulated as a result of the 
hasty completion of the Dillon Round (itself a result of the imminent expiry of the US negotiating mandate) were to be satisfied in the new round. Agriculture was to be a major part of the Kennedy Round, as the topic had largely been shelved in the Dillon Round. An investigation by the Kennedy administration into the areas of future export growth had highlighted agriculture as a sector that had significant potential, blocked at present by the protectionist policies of other countries. So the US turned from a country reluctant to discuss agriculture in the GATT to a major demandeur for progress in trade liberalization in that area. The US included in the mandate for the round the provision that there should be "acceptable conditions of access to world markets for agricultural products."

One aspect of the Kennedy Round illustrates the emerging divergence of opinion over the way to deal with agricultural trade within the multilateral trade system. The US sought to include agriculture more fully in the GATT disciplines by restricting the use of subsidies and lowering tariffs faced by its export products. The EEC championed a proposal for market management that would firm up world market prices and make them more stable. This would of course have had the side advantage of making it easier to manage the domestic EEC market, but the element of market management ran counter to the aims of the US for the future of the trade system.

Indeed, it would be difficult to fault the EEC for lack of proposals for the treatment of agriculture in the round. Early in the talks the EEC introduced a proposal based on the Baumgartner-Pisani Plan for organizing world markets, which had first been discussed in the context of the 1961 International Wheat Agreement (Warley, 1976). Though detailed provisions were not revealed, this plan would have: paid poor countries prices for their commodity exports that would reflect their developmental needs; set agreed volumes of exports from developed countries to other developed countries at agreed prices that were supposed to match the cost of production in the importing countries (and hence be higher than world prices); and set exports to developing countries at discounted prices, the cost being paid from a fund supported by developed countries. Agreement would be reached among developed countries on production policies, export volumes, market shares, and the size and location of stocks (Warley, 1976, p. 394). Perhaps wisely, the US did not take the plan seriously: only the Soviet Union could have dreamed up such a complex scheme for replacing prices with quantitative obligations and replacing market forces with political decisions. ${ }^{42}$

42 Lest one dismiss the scheme as merely being a stalling tactic by the EEC it should be noted that the French delegation to the Stresa Conference had suggested similar planning for EEC agriculture. And Edgar Pisani, a co-author of the plan, was the French minister of 
The second concept that the EEC floated as a way to deal with agricultural trade problems was that of binding levels of support (montant de soutien). The proposal, strongly backed by the French government, involved the binding of the gap between the domestic support price in the local markets and the price on world markets. This plan also was rebuffed by the US and other exporters that wanted to reduce support levels (in Europe) and not give them credibility and permanence. ${ }^{43}$ But this concept had a more plausible basis. It had the merit, as Warley (1976) pointed out, "of cutting across a maze of measures that government used to support prices, and of directing attention to trade distorting effects of those interventions" (p.383). The EEC considered the proposal a valuable concession, but this was not apparent to the exporters. It would have instituted a set of rules for agricultural trade that was different from that of other products. It would have spread these new rules to all agriculture commodities rather than just the grains and oilseeds that were the focus of the Kennedy Round talks. But it does have a more modern ring to it: the aggregate measure of support (AMS) introduced in the Agreement on Agriculture negotiated in the Uruguay Round contains many of the same features as the montant de soutien proposal (as discussed more fully in Chapter 3).

After a second rebuff to its conceptual approach to agricultural trade the EEC reluctantly agreed to discuss access guarantees into its own market. The access was to be expressed in terms of self-sufficiency bindings. The EEC was prepared to bind its self-sufficiency for grains at 90 percent (and the UK at 75 percent), but these were actually higher than the existing levels. Once again the exporters felt that they were getting no additional market access and could not accept the proposal. In retrospect the bindings, if they could have been honored, might have forced the EEC into supply control or much lower prices. But even that offer was tied to the declaration by the International Wheat Council of a "surplus" situation, itself triggered by the world price falling below a "reference" price (Warley, 1976, p. 385).

The notion of addressing problems of agricultural trade through international commodity agreements has a long history. It was not surprising that at the end of the day the negotiators fell back on the notion of a

agriculture who chaired the Council meeting that finally agreed on the 1962 CAP package mentioned above.

${ }^{43}$ Under the EEC proposal the bindings would have lasted for three years, but this could have been a focus of negotiation if the proposal had been better received. The EEC negotiators, however, proposed the plan as a concession that would have taken agriculture out of the talks and was not to be seen as the basis for further discussions. 
weak agreement that could be sold at home as a step towards some goal of better-disciplined markets. The commodity agreement that emerged from the Kennedy Round, the International Grains Arrangement (IGA), was a sad compromise and did not survive the test of the market. The IGA contained a Wheat Trade Convention (WTC) that attempted to set a reference price for wheat, and a Food Aid Convention (FAC) that committed developed countries to a particular target for food aid. The WTC reference price was to trigger action if prices fell below that floor. Within 12 months of the signing of the WTC prices did indeed fall below the floor level, but no action was taken. The FAC fared somewhat better, but it had negligible effect on markets. But it is worthy of note that at the time even the US, in spite of its less interventionist approach to agricultural policy, was willing to conclude an IGA that aimed at managing markets. ${ }^{44}$ It even tried to promote commodity agreement on products that it imported. A Meat Import Law was passed in 1964 that essentially forced Australia and New Zealand to limit their sales of beef and lamb to the US market, but the effort to negotiate a multilateral meat agreement was unsuccessful. The US had even sought the help of the exporters to negotiate a dairy agreement, which could have relieved pressure on the US market, but the dairy talks also ended with no conclusion.

The Kennedy Round concluded in June 1967 with little progress toward the incorporation of agriculture fully into the trade system. Agricultural and food products were included in the across-the-board tariff reductions agreed, though many "sensitive" items were excluded from a general formula cut. In terms of US-EEC trade relations, there were essentially no additional constraints placed on the CAP by the outcome. Of course, the timing was not optimal. As with the Dillon Round the EEC was still in the process of completing the CAP, hampered by the internal controversies over majority voting and common funding, and found it difficult to negotiate access with outside suppliers.

Could there have been a different outcome to the Kennedy Round? How much of the difference in approach between the US and the EEC was convenience rather than principle? And how much simply reflected the distinction of interests between the US as a major exporter and the EEC as a significant importer of farm products?

\footnotetext{
44 One motivation for the US to reverse its stand on an international commodity agreement was the desire to reduce government costs in managing surpluses of grain.
} 


\section{THE CONSEQUENCES FOR TRANSATLANTIC RELATIONS}

It is difficult to paint the picture of transatlantic trade relations in farm products in the 1960s as anything other than an inconclusive and divisive mess. By the end of the 1960s the failure to resolve the basic problems of trade in farm products had generated significant transatlantic tensions.

Perhaps the key causal factor of the difference between the US and EEC policies for agriculture in the 1960s was the domestic price levels that the policies sought to maintain. The differences in policy instrumentation would have been less relevant if prices had been comparable. But prices set by politicians represent a mix of pressures from various constituencies and fundamental constraints from budget targets. In the political economy of price fixing the organized producer groups usually have a strong voice. But this is not to say that governments on each side of the Atlantic were unaware of the effect of farm prices on food consumers. And the budget cost of farm support policies is always a political consideration. But the way in which such objectives are expressed in farm policy decisions can differ.

A way of representing the differences in policy over this period is to compare the transfers to farmers generated by agricultural policy through border protection, input subsidies and direct payments (or deficiency payments). The OECD has developed over the years a database of information on support levels, based upon the notion of an estimate of the producer support generated by the various elements of farm programs. This producer support estimate (PSE) database can track changes in policy over time and is comparable across countries. However, the database extends back only to 1986. Similar statistics were, though, recently collected by the World Bank in a study that included over 80 countries worldwide, and attempted to include data from 1955 onwards to see the development of policies over a long period. Data exist in the World Bank database that make it possible to reconstruct a "PSE-type" measure for the earlier years. Figure 1.2 shows the percentage PSEs for the EEC and the US generated from the World Bank database. ${ }^{45}$

Several features of Figure 1.2 illustrate the narrative of this chapter.

45 This figure is derived from the database developed for the World Bank study on agricultural distortions as updated in 2012 (Anderson and Nelgen, 2013). Interpretations of the policy developments in the US and EU based on this study are found in Gardner (2009) and Josling (2009). For the figure presented here, "gross subsidy value" as defined in the World Bank database (the sum of transfers from border protection, input subsidies and direct payments) was related to the value of production including such transfers, to make the indicator as comparable as possible to the PSE that is included in the OECD database. 


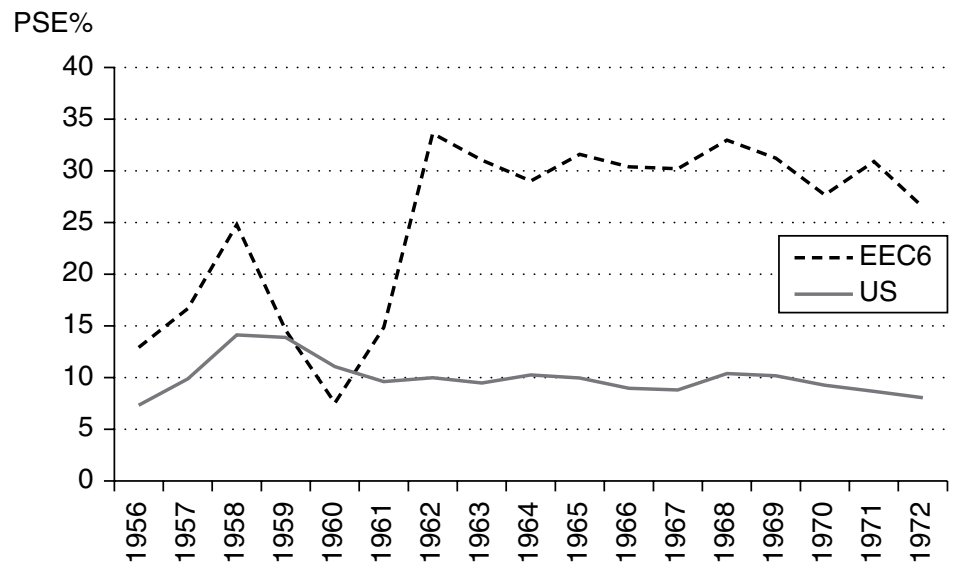

Note: Producer support equivalent as percentage of gross farm receipts.

Source: Authors' calculations based on World Bank Agricultural Distortions database.

Figure 1.2 US and EEC producer support equivalents, 1956 to 1972

First, the levels of protection were essentially similar and modest in the mid-1950s and again were comparable by 1960 . So the high support levels in the EEC were not apparent at the time of the Dillon Round. The EEC had yet to decide on the form and instrumentation of its agricultural policy and in particular the product price levels it would support. But it does not appear that the situation before the CAP was introduced was one of widely divergent support levels between the European countries that were to form the EEC and the US. However, the creation of the CAP and its implementation caused the support levels to increase by a factor of three, while the US support started a slow decline. The elevated support levels persisted through the 1960s and gave grounds for the fears of the US that the CAP was a highly protectionist policy. From the point of view of the EEC the high levels of support were a small price to pay for the integration of markets, and were in any case necessary for the building up of a strong agricultural sector that would ensure food security.

On both sides of the Atlantic there has been a tendency to assume that high levels of food security require high domestic production. This has led to confusion as to how to incorporate world markets into the broader aspects of food strategy. This ambiguity is clearly apparent in the development of EEC food policy in the first few years. In the 1950s fresh memories of acute food shortages in the immediate post-war period were reflected 
in the emphasis on building up the capacity of European agriculture. ${ }^{46}$ However, as pre-war levels of food production had generally recovered by 1950 and surpluses were beginning to appear in some commodities, food supply policies were essentially incidental consequences of limiting imports for the protection of the domestic producer. ${ }^{47}$

Food shortages had not been part of the US national experience, though obviously poverty-related hunger was present in the 1950s. Nevertheless the link between stimulating domestic production and assuring affordable food for consumers was rarely challenged in the US. Gardner (1992) confirmed that "there is a perception that an economically healthy agriculture is a kind of food-supply insurance for consumers, and this contributes to support for the protection of agriculture."

At the inception of the European Economic Community the conflation of food availability and domestic production was taken for granted. Food policy was administered by the Agricultural Directorate-General of the Commission (DGVI) and came under the wing of the commissioner for agriculture. Article 39 of the Treaty of Rome, which obligated the EEC to develop a Common Agricultural Policy, gave lip service to the need to "ensure adequate food supplies for consumers at reasonable prices," though this obligation has clearly had little effect on policy. Consumer groups were in their infancy in the early years of the EEC and had only indirect access to senior officials. ${ }^{48}$

The instruments used by the CAP were successful in their own terms, as the landed price of imports and the floor price at which surpluses were taken into intervention kept a stable domestic market price for the major products. If the common prices had been significantly lower one might have been able to conclude that the CAP had a good first decade. But the incentive to produce and to adopt modern farming practices yielded surpluses on the domestic market that would prove the main challenge for the CAP in the years ahead.

The commodity mix also played into the conflicts. Many of the tensions

46 An additional factor was the "shortage" of foreign exchange. This appeared to bolster the case for increasing self-sufficiency.

47 The UK was an exception, as imports of foodstuffs from the British Commonwealth were allowed in without tariffs. Germany stood at the other extreme, with imports controlled by the Import and Storage Boards for the major commodities (Tracy, 1964, pp. 287ff.). Germany had lagged behind other Western European countries in terms of the increase of agricultural production and reached pre-war levels only in 1956.

48 As an example, the Consumers Consultative Committee of the European Commission attempted to address the issue of why prices for EU foodstuffs should be higher for domestic consumers than for foreign consumers (as a result of export subsidies): this report was never presented to the commissioner responsible for consumer issues (who was a former Italian minister of agriculture), who disagreed with its premise. 
revolved around wheat and soybeans. These commodities were backed by powerful interests in the US, in those parts of the agricultural heartland where concerns over the niceties of trade negotiations were subordinated to the notion that the US was a competitive producer held back only by the obstructive policies of others. Wheat was also an emotional subject in Europe and one where the French had a dominant interest. But there was also little progress in trade talks on the other commodities, where the conflict of interest was less clear. Both the US and the EEC had inefficient dairy sectors that were ripe for consolidation and cost reductions. The US emphasized restrictions on the marketing of milk, and the EEC chose the control of the markets for milk products. In beef, neither the US nor the EEC had a significant exporter position, but this did not imply that they could make their policies consistent in this area. Similarly with sugar, though complicated by post-colonial relationships in the EEC, the chance was lost to discuss the international market for a key import commodity.

One can speculate on the chances that were missed in the 1960s to strengthen rather than weaken the Atlantic partnership. The Chicken War was seen as a symbolic act to send a "shot across the bow" of the CAP. But the real dispute was a technical one over the meaning of the September 1960 standstill agreement and the value of US trade lost. Surely there must have been better ways of defusing tensions at a time of institutional change. Similarly, the Dillon Round looks in hindsight as being of little practical value, and the attempt of the US to secure its access in the EEC markets was quixotic at best. But it is the Kennedy Round, at least in agriculture, that marked the inability of negotiators to engage in a way that promoted the development of a trade system that would embrace both US and EEC interests and allow the trade relationship to proceed in a fruitful way.

Perhaps it was inevitable that the US and the EEC could not agree on the way in which agriculture should be treated in the trade system. There were certainly some differences in political philosophy in evidence. But neither side of the Atlantic seemed to understand the other: indeed it seems as if to understand the position of the other side in negotiations was seen as a weakness. By the time the Kennedy Round reached the final stages of negotiations, and compromises might have been possible, both sides had convinced themselves that the other was incapable of movement. Attempts at overcoming the lack of real progress were left until the next round of trade talks, the Tokyo Round. However, trade policy was overtaken by events that were dramatic even by the standards of the 1960s.

It is possible to see in the 1960s trade conflicts the major fault of the CAP emerging: the inflexibility of a pricing system that encouraged bulk commodities for which the market was stagnant over higher-value products 
where the demand was growing at home and abroad. By the early 1970s the surpluses that were emerging demonstrated this design flaw in the CAP, but by that stage inflexibility was replaced by rigidity. But then it is also fair to say that neither the US nor the countries of Western Europe put a high priority on the ramifications of their policies on the workings of international markets. Both considered that the world market was an extension of their domestic programs: to absorb surplus production or to satisfy excess demand as the occasion arose.

The events of the 1960s had set the scene for the tensions to follow in the next two decades. As in a Greek tragedy, the conflicts became inevitable as each side of the Atlantic interpreted events according to its own viewpoint. The US supported European integration but misunderstood the role of the CAP in that process. It treated the fledgling institutions of the EEC as if they were mature countries able to bargain at the international table. The EEC members were looking inward and acted as if they neither knew nor cared what was happening on world markets. The decade ended with a lack of any accommodation in the area of agricultural and food trade, leaving a burr under the saddle of transatlantic relations. 